\title{
ALTERED INTRAHEPATIC HEMATOPOIESIS IN NEONATES FROM WOMEN WITH PREGNANCY INDUCED HYPERTENSION/PRE-ECLAMPSIA
}

\author{
Demetrio Tamiolakis ${ }^{1}$, Ioannis Venizelos ${ }^{2}$, Maria Lambropoulou ${ }^{3}$, Anna Efthymiadou ${ }^{3}$, Vasiliki Arvanitidou ${ }^{3}$, \\ Panagiotis Tsikouras $^{4}$, Gerasimos Koutsougeras ${ }^{5}$, George Chimonis ${ }^{5}$, Demetrio Karamanidis ${ }^{5}$, Sophia Barbagadaki ${ }^{1}$, \\ Sylva Nikolaidou ${ }^{1}$, Evagelia Seliniotaki ${ }^{1}$, Panagiotis Boglou $^{3}$, Nikolas Papadopoulos ${ }^{3}$
}

General Hospital of Chania, Greece: Department of Cytology ${ }^{1}$; Ippokration Hospital of Salonica, Greece: Department of Pathology ${ }^{2}$; Democritus University of Thrace, Greece: Department of Histology-Embryology ${ }^{3}$, Department of Obstetrics and Gynecology ${ }^{4}$; General Hospital of Alexandroupolis, Greece: Department of Obstetrics and Gynecology ${ }^{5}$

Summary: Aim: To detect whether preeclampsia influences neonatal intrahepatic hematopoiesis, given that an activation of fetal neutrophils and monocytes during the course of this disorder occurs. Experimental design: We examined liver samples from 10 neonates of hypertensive/preeclamptic women at 27 to 28 weeks of gestation delivered by a cessarian section. All neonates were placed in incubators but they all died within 24 hours due to immaturity. The control group comprised 10 fetuses of the same gestational age, after voluntary abortion due to a neural defect. Specific antibodies against CD34, glycophorin C, hemoglobins A and F, myeloperoxidase, CD61, CD68, terminal desoxynucleotidyl transferase and the pax-5/B-cell specific activator protein, were used in each sample. Results: Neonates from hypertensive/preeclamptic women, in comparison with controls, showed: a statistically significant reduction of erythropoiesis by $25 \%(\mathrm{p}=0.015)$; a statistically significant increase of granulopoiesis $(\mathrm{p}=0.019)$; a statistically significant increase in the expression of CD68 positive cells of the monocytic lineage $(\mathrm{p}=0.017)$; a statistically significant increase in the expression of CD34 progenitor/stem positive cells $(\mathrm{p}=0.021)$. No statistically significant differences were observed in both examined groups, concerning megakaryopoiesis and B lymphopoiesis. Conclusions: Preeclampsia of pregnancy has an impact on neonatal intrahepatic hematopoiesis by increasing granulopoiesis, reducing erythropoiesis and triggering endothelial and stem cell activation. We suggest that these findings reflect a state of persistent inflammation and a loss of red blood cell production possibly contributing to the neonatal morbidity related to this disorder.

Key words: Preeclampsia; Neonatal liver hematopoiesis; Hematopoietic markers

\section{Introduction}

Preeclampsia, a severe hypertensive disorder in pregnancy, represents one of the major causes of maternal and fetal mortality in developing countries. The etiology of the condition is unknown, but placental disorders are probably involved in the pathophysiologic mechanism (16). Both the fetus and the placenta are often growth retarded when hypertension occurs before mid-gestation. There are ischemic changes and often-placental infarcts. Onset of preeclampsia in early gestation greatly increases the risk of spontaneous abortion, abruptio placenta, fetal death, spontaneous pre-term labor, and pre-term delivery.

In mid-trimester fetuses the principal site of hematopoiesis is the liver, where two functionally different compartments can be observed. Erythropoiesis mainly takes place within the sinusoids of the parenchyma while granulopoiesis is restricted to the mesenchymal tissue of the portal fields.
Impaired intrahepatic hematopoiesis has been demonstrated mainly in fetuses with chromosomal abnormalities such as Trisomy 21 (Down's syndrome) $(1,8,23)$ and Trisomy $13(10,18,27)$, and lesser in fetuses with viral infections $(7,13,6,14,12)$.

It is known that activation of fetal neutrophils and monocytes during preeclampsia involves enhanced chemokine activation, which contributes to the fetal morbidity of this disorder (17). To elucidate whether this activation of fetal neutrophils and monocytes is associated with respective changes at the level of intrahepatic hematopoiesis, we examined by using immunohistochemistry liver samples from neonates from preeclamptic women and correlated our findings with those after voluntary abortion (control group)

\section{Materials and methods}

Ten newborns with gestational age 27 to 28 weeks, from hypertensive/preeclamptic women delivered by a cesarean 
section, were examined. All subjects were admitted to the intensive care unit for neonates. Incubators were used to maintain an environment with controlled temperature, humidity and oxygen for development of the premature infants. However, none of them could make it within the next 24 hours due to immaturity. All cases fulfilled the criteria of severe preeclampsia which were based on the definitions given by Davey and MacGillivray (4). Gestational hypertension was defined as the occurrence, in a previously normotensive woman, of a diastolic blood pressure $90 \mathrm{mmHg}$ on at least two consecutive occasions after the $20^{\text {th }}$ week of gestation. Preeclampsia was defined as the association of gestational hypertension with significant proteinuria $(>300$ $\mathrm{mg} / \mathrm{l}$ in a 24-h urinary collection). The corresponding placentas showed increased amounts of perivillous fibrin, dense leukocytic infiltration, and more than $15 \%$ of the parenchyma was affected by infarction. The histologic examination of the placenta was done according to a standardized protocol stating signs of developmental disturbance and with particular reference to indices of infection.

An equal number of fetuses at the same gestational age after voluntary abortion due to a neural tube defect, were used as controls. No microscopic placental changes have been found. The study was carried out in harmony with the guidelines for the analysis of fetal cells and tissues (26) and approved by the Regional Committees of Ethics. Written informed consent was obtained from all women, and the procedures followed were in accordance with the institutional guidelines.

Tissue sections from both lobes of the liver for each case were prepared. For conventional analysis the sections were stained with hematoxylin and eosin (H\&E). To detect a variety of antigens related to hemato- and lymphopoiesis, a panel of monoclonal and polyclonal antibodies was applied. The antibodies used were directed against CD34 (clone QBEnd 10), glycophorin C (clone Ret40), hemoglobins $\mathrm{A}$ and $\mathrm{F}$ (polyclonal), myeloperoxidase (MPO-7, polyclonal), CD61 (clone Y2/51), CD68 (clone KP1 and PG-M1), terminal desoxynucleotidyl transferase (TdT, polyclonal) and the pax-5/B-cell specific activator protein (clone 24). With the exception of the anti-CD34 and antipax-5 antibodies, which were obtained from CoulterImmunotech, Krefeld, Germany, and Becton Dickinson Biosciences, Lexington, Kentucky, U.S.A., respectively, all other antibodies were purchased from DAKO, Glostrup, Denmark. For demasking of most of the antigens a high pressure cooking technique was used applying $10 \mathrm{mM}$ citrate buffer $\mathrm{pH} 6.0$ while demasking glycophorin $\mathrm{C}$ and CD61 required proteolytic treatment. Bound antibodies were visualized employing the alkaline phosphatase (APAAP) method and Fast Red for development. For identification of mature granulopoietic cells, the histochemical detection of Naphtol-AS-D-chloroacetate estearse (SIGMA Diagnostics, St Louis, MO, USA) was employed.

The statistical analysis was obtained using the non-parametric Mann-Whitney test. The mean values were expressed as average SD.

\section{Results}

Five microscopic fields of the parenchyma of the liver were evaluated in each case without knowledge of the clinical data, and the number of stained cells per square millimeter was calculated. We identified islands of hematopoietic cells using conventional histology within the fetal liver parenchyme. Immunohistochemical analysis then facilitated the precise definition of the various lineages. The sections were examined independently by two observers, and positive cellular staining for each antibody was manifested as fine red cytoplasmic granularity.

The liver of fetuses after voluntary abortion showed a distinct distribution of hematopoiesis. Erythropoiesis (evidenced by positive expression of glycophorin $\mathrm{C}$, and hemoglobins $\mathrm{A}$ and $\mathrm{F}$ ) occurred in aggregates mainly within the sinusoids of the hepatic parenchyme (averaged of 3820640 cells $/ \mathrm{mm}^{2}$; range $2800-4900$ cells $/ \mathrm{mm}^{2}$ ) (Fig. 1). Granulopoiesis (based on the detection of positive expression of myeloperoxidase and chloroacetate esterase) occurred primarily within the mesenchymal stromal cells of the portal fields (averaged: 32.517 .8 cells $/ \mathrm{mm}^{2}$; range $12-75$ cells $/ \mathrm{mm}^{2}$ ) (Fig. 2). Monocytopoiesis (documented by positive expression of CD68) was found within the mesenchymal stromal cells of the portal fields (averaged: 2.650 .73 cells $/ \mathrm{mm}^{2}$; range $1.8-3.9$ cells $/ \mathrm{mm}^{2}$ ) (Fig. 3). The anti-CD34 antibody led to labeling of the endothelial cells of numerous sinuses, while numerous CD34-positive blasts mainly within the stroma of the portal fields, were discernible (averaged: 45.715 .2 cells $/ \mathrm{mm}^{2}$; range $18-73$ cells $/ \mathrm{mm}^{2}$ ). Furthermore, a number of cells expressing CD61 were identified; this is characteristic for megakaryocytes. Using morphological criteria, these cells comprised a spectrum ranging from small cells with unilobated nuclei to large multilobated megakaryocytes (averaged: 3.120 .38 cells $/ \mathrm{mm}^{2}$; range $2.1-4.2$ cells $/ \mathrm{mm}^{2}$ ). The antibody specific for pax-5/B-cell specific activator protein labeled single nucleated cells corresponding to B lymphocytes (averaged: 5.680 .96 cells $/ \mathrm{mm}^{2}$; range $4.2-7.8$ cells $/ \mathrm{mm}^{2}$ ). Terminal desoxynucleotidyl transferase (TdT)-positive cells were not identified either in the portal fields, or in any other region of the fetal hepatic sample.

Morphological and immunohistological analysis of the neonatal liver samples from hypertensive/preeclamptic women showed: 1) A severe reduction of erythroid cells by $25 \%$ (averaged: 2890760 cells $/ \mathrm{mm}^{2}$; range $2300-4500$ cells $/ \mathrm{mm}^{2}$ ) (Fig. 4) which was statistically significant $(p=0.015) .2)$ An intense granulopoietic activity in the mesenchymal tissue of the portal fields extending into the sinusoids (Fig. 5). The number of granulopoietic cells was more than 2 times higher than that found in the voluntary abortion group (averaged: 70.432 .7 cells $/ \mathrm{mm}^{2}$; range $25-160$ cells $/ \mathrm{mm}^{2}$ ). Comparing the granulopoietic activity in the two groups we found a statistically significant difference $(p=0.019)$, favoring the preeclamptic pregnancies. A similar pattern was observed for the monocytic lineage (averaged: 


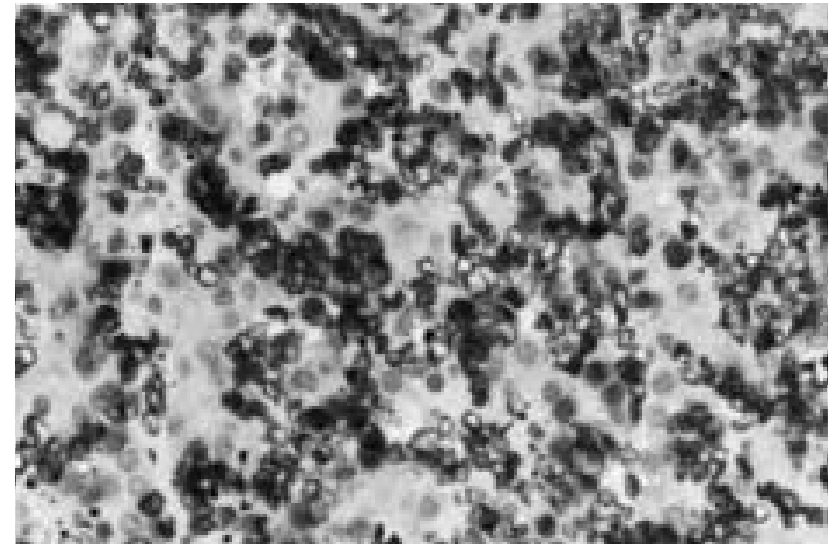

Fig. 1: Control group: Erythropoietic cells within the hepatic sinuses expressing glycophorin $\mathrm{C}$. Immunostaining using APAAP technique (red labeled cells), X400.

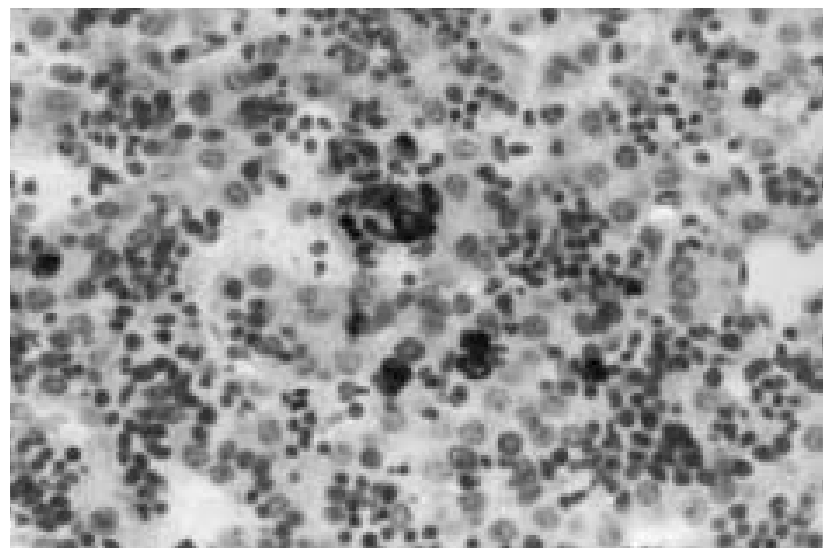

Fig. 3: Control group: Monocytes expressing the CD68 antigen. Immunostaining using APAAP technique (red labeled cells), X400.

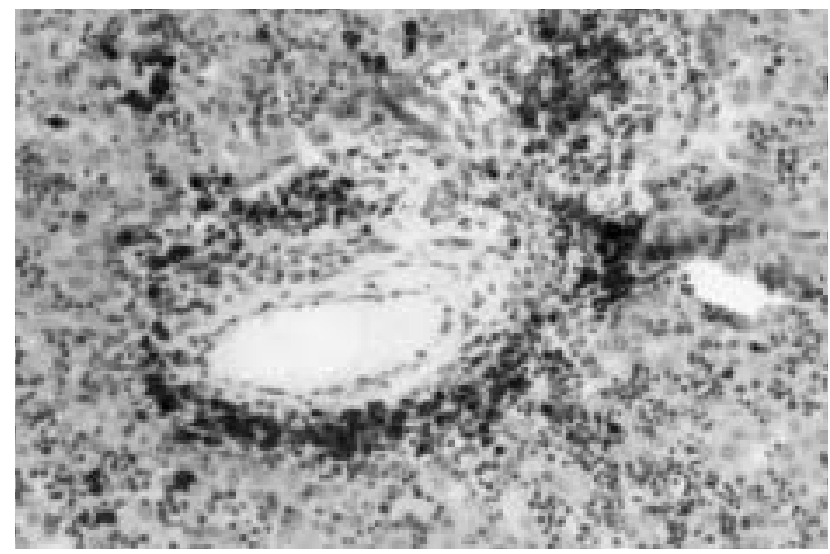

Fig. 5: Preeclamptic group: Myeloperoxidase-positive cells of granulocytic lineage within the mesenchymal tissue of the hepatic portal fields. Immunostaining using APAAP technique (red labeled cells), X200.

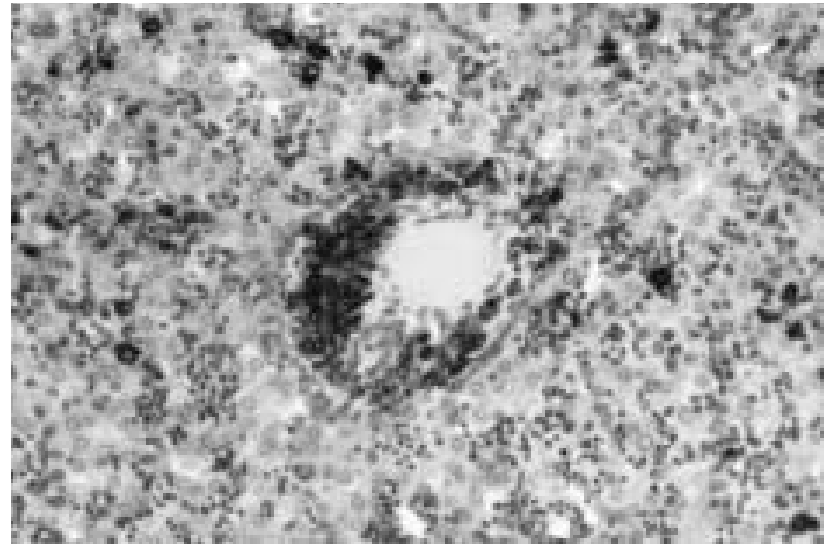

Fig. 2: Control group: Myeloperoxidase-positive cells of granulocytic lineage within the mesenchymal tissue of the hepatic portal fields. Immunostaining using APAAP technique (red labeled cells), X200.

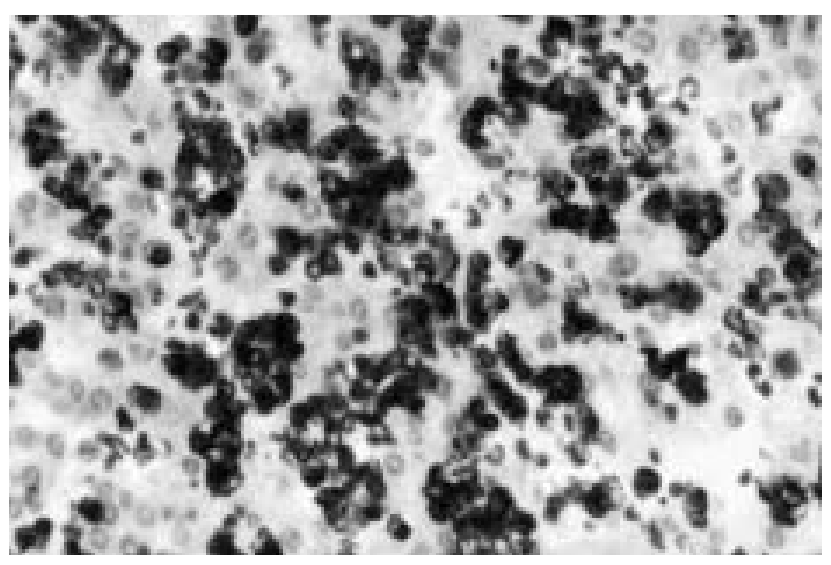

Fig. 4: Preeclamptic group: Erythropoietic cells within the hepatic sinuses expressing glycophorin C. Immunostaining using APAAP technique (red labeled cells), X400.

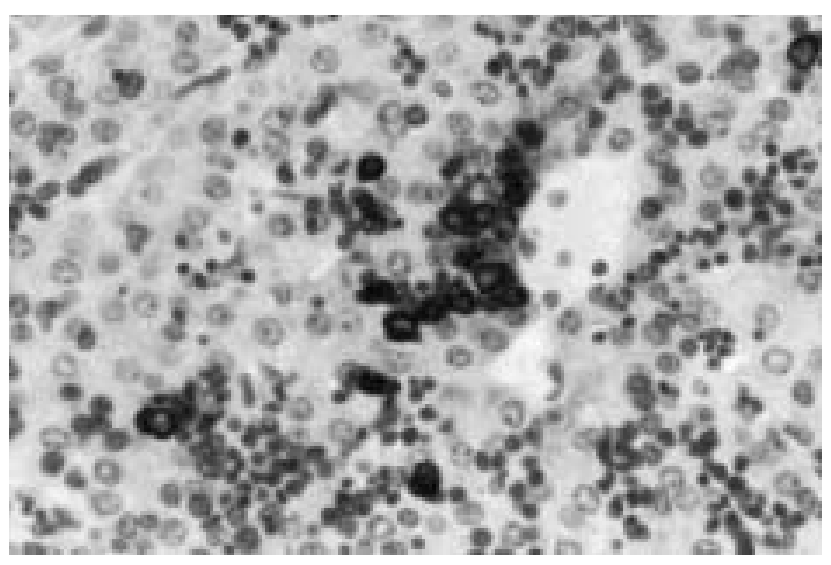

Fig. 6: Preeclamptic group: Monocytes expressing the CD68 antigen. Immunostaining using APAAP technique (red labeled cells), X400. 
Tab. 1: Descriptive characteristics of the liver samples from the two examined groups $\left(27^{\text {th }}-28^{\text {th }}\right.$ weeks of gestation).

\begin{tabular}{|l|c|c|c|}
\hline & Control group & Preeclamptic group & Statistical analysis \\
\hline Erythropoiesis (cells $/ \mathrm{mm}^{2}$ ) & $3820 \pm 640$ & $2890 \pm 760$ & $\mathrm{p}=0.015$ \\
\hline Granulopoiesis (cells $/ \mathrm{mm}^{2}$ ) & $32.5 \pm 17.8$ & $70.4 \pm 32.7$ & $\mathrm{p}=0.019$ \\
\hline Monocytopoiesis (cells $/ \mathrm{mm}^{2}$ ) & $2.65 \pm 0.73$ & $3.65 \pm 0.81$ & $\mathrm{p}=0.017$ \\
\hline $\begin{array}{l}\text { Progenitor hematopoietic cells and vascular } \\
\text { endothelial cells (cells } / \mathrm{mm}^{2} \text { ) }\end{array}$ & $45.7 \pm 15.2$ & $68.1 \pm 20.8$ & $\mathrm{p}=0.021$ \\
\hline Megakaryocytopoiesis (cells $/ \mathrm{mm}^{2}$ ) & $3.12 \pm 0.38$ & $3.21 \pm 0.79$ & $\mathrm{NS}$ \\
\hline B Lymphopoiesis (cells $/ \mathrm{mm}^{2}$ ) & $5.68 \pm 0.96$ & $5.85 \pm 1.08$ & $\mathrm{NS}$ \\
\hline
\end{tabular}

3.650.81 cells $/ \mathrm{mm}^{2}$; range 2.3-4.8 cells $/ \mathrm{mm}^{2}$ ) (Fig. 6). Comparing the two examined groups at the level of CD68 we found a statistically significant difference $(p=0.017)$ favoring the preeclamptic deliveries. The quantitative expression of CD34 by the vascular endothelial cells, the progenitor/stem hematopoietic cells and stromal progenitor cells was more intense in the mesenchymal portal tissue and the extending sinusoids (averaged: 68.120 .8 cells $/ \mathrm{mm}^{2}$; range 32-93 cells $/ \mathrm{mm}^{2}$ ). Comparing the two examined groups at the level of CD34 we also found a statistically significant difference $(p=0.021)$ favoring the preeclamptic cases No significant quantitative differences concerning megakaryopoiesis and B lymphopoiesis, were observed, between the two groups. The above results are summarized in table 1 .

\section{Discussion}

Pre-eclampsia of pregnancy refers to a symptom complex characterized by hypertension, proteinuria and edema. It occurs in about $7 \%$ of primiparous women, usually after 20 weeks of gestation (4). Endothelial dysfunction appears to be central in the pathophysiology of this disorder (19) and has also been reported in the fetus $(5,28)$ but the mechanisms leading to this dysfunction have not been clarified. In preeclampsia, there is a faulty shallow placentation, i.e., a reduced invasion of the trophoblast into the uterus and its spiral arteries (3), resulting in a significant reduction in the uteroplacental blood flow (15), with a chronic prenatal fetal hypoxia. Hypoxia has been shown (1) indirectly, in the human umbilical artery and vein, where abnormal Doppler velocity waveforms indicate an increased vascular resistance (25) and hypoxia (11); (2) directly, by increased plasma adenosine (29) and erythropoietin levels (20) reduced $\mathrm{pH}$ and $\mathrm{PO}_{2}$ levels, and increased $\mathrm{PCO}_{2}$ levels in the human umbilical artery and human umbilical vein $(21,24)$; and (3) clinically, by increased frequency of placental infarcts (2). Long-range uteroplacental hypoxemia may produce inflammatory changes in the placenta with the release of inflammatory chemokines, inducing fetal neutrophils' and monocytes' activation, which, in turn, may release additional inflammatory mediators (22). This may make a vicious circle, leading to strong CD34 positive cell activation.

To give insight into possible mechanisms of neonatal morbidity in preeclampsia we focused on intrahepatic he- matopoiesis, in comparison to controls after voluntary abortion. In our settings, the comparative study of the quantitative percentage of:

a) Glycophorin $\mathrm{C}$ and hemoglobins $\mathrm{A}$ and $\mathrm{F}$, showed a reduction of erythropoiesis in preeclamptic pregnancies which was statistically significant $(\mathrm{p}=0.015)$

b) myeloperoxidase and chloroacetase esterase showed a statistically significant elevation of granulopoiesis in preeclamptic deliveries $(\mathrm{p}=0.019)$

c) CD68 for the identification of monocytes showed a statistically significant elevation of monocytopoiesis in preeclamptic deliveries $(p=0.017)$

d) CD34 for the identification of progenitor hematopoietic cells and vascular endothelial cells showed an enhanced hematopoiesis in preeclamptic fetuses over controls $(\mathrm{p}=0.021)$

The quantitative percentages of CD61 and pax-5/B-cell specific activator protein, showed no differences concerning megakaryocytopoiesis and B-lymphopoiesis between preeclamptic and control groups.

Our data imply a loss in red blood cell production and a persistent inflammatory response in preeclampsia, which could explain the morbidity of this disorder. Further investigation is necessary to establish this hypothesis.

\section{References}

1. Becroft DM. Fetal megakaryocytic dyshemopoiesis in Down syndrome: association with hepatic and pancreatic fibrosis. Pediatr Pathol 1993;13:811-20.

2. Brosens I, Renaer M. On the pathogenesis of placental infarcts in preeclampsia J Obstet Gynaecol Br Commonw 1972;79:794-9.

3. Brosens I, Robertson WB, Dixon HG. The role of spiral arteries in the pathogenesis of preeclampsia. In: Wynn RM (ed). Obstetrics and Gynecology Annual. NY: Appelton-Century-Crofts, 1972:pp. 171-91.

4. Davey DA, MacGillivray I. The classification and definition of the hypertensive disorders of pregnancy. Am J Obstet Gynecol 1988;158:892-8.

5. Davidge ST, Signorella AP, Lykins DL, Gilmour CH, Roberts JM. Evidence of endothelial activation and endothelial activators in cord blood of infants of preeclamptic women. Am J Obstet Gynecol 1996;175:1301-6.

6. Dong ZW, Zhou SY, Li Y, Liu RM. Detection of a human parvovirus intrauterine infection with the polymerase chain reaction. J Reprod Med 2000;45:410-2.

7. Grangeot-Keros L, Cointe D. Viral infections and pregnancy: contribution of amniotic fluid and blood samples. Gynecol Obstet Fertil 2001;29:849-9.

8. Hamada H, Yamada N, Watanabe H, Okuno S, Fujiki Y, Kubo T. Hypoechoic hepatomegaly associated with transient abnormal myelopoiesis provides clues to trisomy 21 in the third-trimester fetus. Ultrasound Obstet Gynecol 2001;17:442-4.

10. Huehns ER, Lutzner M, Hecht F. Nuclear abnormalities of the neutrophils in D1(13-15) trisomy syndrome. Lancet 1964;1:589.

11. Joupilla P, Kirkinen P. Umbilical vein blood flow as an indicator of fetal hypoxia. Br J Obstret Gynaecol 1984;91:107-10.

12. Katow $\mathrm{S}$. Rubella virus genome diagnosis during pregnancy and mechanism of congenital rubella. Intervirology 1998;4:163-9. 
13. Labouret N, Cecille A, Wendling MJ, Fritsch S, Gut JP, Stoll-Keller F. Prenatal diagnosis of viral infections. A two-year study in Strasbourg. Pathol Biol (Paris) 1999; $47: 525-30$

14. Liesnard C, Donner C, Brancart F, Gosselin F, Delforge ML, Rodesch F. Prenatal diagnosis of congenital cytomegalovirus infection: prospective study of 237 pregnancies at risk. Obstet Gynecol 2000;95:881-8.

15. Lunell NO, Nylund LE, Lewander R, Sarby B. 1982. Uteroplacental blood flow in preeclampsia measurements with indium-113 and a computer-linked gamma camera. Clin Exp Hypertens 1982;1:105-17.

16. Meekins JW, Pijnenborg R, Hanssens M, McFayden IR, Van Asshe A. A study of placental bed spiral arteries and trophoblastic invasion in normal and severe preeclamptic pregnancies. Br J Obstet Gynecol 1994;101:669-74.

17. Mellembakken JR, Aukrust P, Hestdal K, Ueland T, Abyholm T, Videm V. Chemokines and leukocyte activation in the fetal circulation during preeclampsia. Hypertension 2001;38:394-8.

18. Powars D, Rhode R, Graves D. Foetal hemoglobin and neutrophilic anomaly in the D1 trisomy syndrome. Lancet 1964;1:1363.

19. Roberts JM, Taylor RN, Musci TJ, Rodgers GM, Hubel CA, McLaughlin MK Preeclampsia: an endothelial cell disorder. Am J Obstet Gynecol 1989; 161:1200-4.

20. Ruth V, Fyhrquist F, Clemons G, Raivio KO. Cord plasma vasopressin, erythropoietin, and hypoxanthine as indices of asphyxia at birth Pediatr Res 1988; 24:490-4.

21. Salafia CM, Minior VK, Lopez-Zeno JA, Whittington SS, Pezzulo JC, Vintzileos AM. Relationship between placental histologic features and umbilical cord blood gases in preterm gestations. Am J Obstet Gynecol 1995;173:1058-64.

22. Stallmach T, Karolyi L, Lichten $P$ et al. Fetuses from preeclamptic mothers show reduced hepatic erythropoiesis. Pediatr Res 1998;43:349-54.

23. Tamiolakis D, Papadopoulos N, Karamanidis D et al. The immunophenotypic profile of hepatic hemopoiesis in fetuses with Down's syndrome during the second trimester of development. Clin Exp Obstet Gynecol 2001;28:153-6.
24. Tervila L, Vartiainen E. Acid-base relationship between mother and fetus in gestosis (pre-eclampsia) and in pregnant women with a labile blood pressure. Acta Obstet Gynecol Scand 1975;54:251-3.

25. Trudinger BJ, Giles WD, Cook CM. Fetal umbilical artery velocity waveforms and placental resistance: clinical significance. Br J Obstret Gynaecol 1985;92:23-30.

26. Vilmar K. Wolff HP. Richtlinien zur Verwendung fetaler Zellen und fetale Gewebe. Dt rztebl 1991;88:48-52

27. Walzer S, Gerald PS. Hematologic changes in the D1 trisomy syndrome. Pediatrics 1966;34:419.

28. Wang Y, Adai CD, Coe L, Weeks JW, Lewis DF, Alexander JS. Activation of endothelial cells in preeclampsia: increased neutrophil-endothelial adhesion correlates with up-regulation of adhesion molecule P-selectin in human umbilical vein endothelial cells isolated from preeclampsia. J Soc Gynecol Investig 1998;5: 237-43.

29. Yoneyama Y, Sawa R, Suzuki S, Shin S, Power G, Araki T. The relatioship between uterine artery Doppler velocimetry and umbilical venouw adenosine levels in pregnancies compicated by preeclampsia. Am J Obstet Gynecol 1996;174:267-71.

Submitted January 2004.

Accepted March 2004.

Nikolaos Papadopoulos,

Assoc. Professor in Histology-Embryology,

Democritus University of Thrace,

Dragana, 68100 Alexandroupolis,

Greece.

e-mail: npapad@med.duth.gr 